\title{
The Causes and Characteristics
}

\author{
C. NANA DERBY
}

L'esclavage a été aboli partout dans le monde pendant les années 1880. Toutefois les femmes et les enfants continuent de travailler dans des conditions d'esclaves. Cet article aborde les

\section{Much like the chattel slaves of the past, trafficked victims are also sold by a "master" (the trafficker) and exploited until the expiration of their indenture.}

causes et les caractéristiques de l'esclavage contemporain et le distingue des esclavages passés.

The word "slave" derives from the Latin word servus which means "a person whose life has been spared (servatus) by the captor" (cited in Archer 267). Today, slavery is defined as a "social and economic relationship in which a person is controlled through violence or its threat, paid nothing, and economically exploited" (Bales 2000: 3). Originally, debt bondage and indentured servitude were not considered as dehumanizing as chattel slavery or serfdom; thus no efforts were made to eliminate them from societics. Debt bondage and indentured servitude therefore largely replaced slavery when it was finally abolished in the $1880 \mathrm{~s}$. They have, however, assumed attributes that are akin to past forms of enslavement. This paper looks at some of the causes of what I argue are forms of contemporary slavery.

Historically, existing alongside chattel slavery and serfdom were debt bondage and indentured servitude. There were two phases of indentured servitude (Bush). The first existed in the period between the seventeenth and eighteenth centuries, while the second stretched from the nineteenth through early twentieth centuries. Merchants privately organized the first phase of indentured servitude, while the British, Swiss, French and German governments publicly organized the second (Bush). In the first phase which ended with the onset of slavery, labour was obtained through indentures from European countries particularly for tobacco cultivation in North America and the Caribbean. The second phase was necessitated by the abolition of slavery. In this era, the governments recruited non-European indentured servants from Africa and Asia to work on sugar plantations in the Americas (Bush).

Acquisition of labour through indentures came to an end when it was abolished by the British government in 1916. Like debt bondage, indentured servitude also resulted from financial obligations. Debtors traveled long distances to work on plantations, and their employment was based on indenture contracts. This contract bound men and women for three to five years of service in a distant land (Bush; Engerman, Drescher and Paquette).

Historically, debt bondage usually resulted from financial obligations that were due to the supposed "masters" or the beneficiaries of the services. I would argue that these forms of indenture manifest themselves in twentieth century forms of migration and trafficking. This is evidenced in the development of international agreements which continue to make use of terminology such as indenture and debr bondage. For example, in the 1956 Supplementary to the 1926 Slavery Convention, debt bondage is defined as

the status or condition arising from a pledge by a debtor of his personal services or those of a third person under his control as a security for a debt, where the value reasonably assessed of those services rendered is not applied towards the liquidation of the debt or the length and nature of those services are not respectively limited and defined.

Kevin Bales (2000) identifies two types of debt bondage. In the first, the slaves' lives and labour are used as collateral for the acquisition of loans. But their bondage does not end with the collateral-they will have to work towards the payment of the loans and the accruing interests. In the second form of debt bondage, the victims become bonded slaves only when they violate the loan agreements (Bales 2000, 1999). According to Bales (1999, $2000)$, there are approximately 27 million slaves scattered around the world today. Between 15 and 20 million of these are bonded slaves.

Similarly, indentures are not unlike the fake contracts that traffickers use in contemporary slavery since, in reality the indentured servant (trafficked victim) would remain the property of the person who paid the travel expenses until they were sold to a "master." These temporary forms of forced servitude have served as the link between chattel slavery and contemporary slavery (Derby). Like the distinction between slavery on one hand and 


\section{of "Contemporary Slavery" Impacts on Women and Girls}

temporary forms of forced servitude on the other, the major distinction between chattel slavery and contemporary slavery is the assertion of legal ownership in the former. In both the temporary forms of forced servitude and contemporary slavery, the victims are procured and disposed of when the perpetrators deem it appropriate and beneficial.

I believe that the trafficking of women and children around the world today for domestic work, agricultural labour or for prostitution is a form of contemporary slavery. In this article, I identify the movement of people from one place to another as "trafficking" if unsuspecting victims are enticed with the promises of job opportunities and financial prosperity, or kidnapped and coerced forced to engage in other activities that are exploitative and enslaving at their destination. Much like the chattel slaves of the past, trafficked victims are also sold by a "master" (the trafficker) and exploited until the expiration of their indenture (Bush).

\section{Past and Present Manifestations of Slavery}

Just before slavery was abolished, laws that governed the temporary forms of forced servitude were established to ensure the continued supply of free labour on the plantations in the Americas. In Pennsylvania in 1780, laws that required that slave children remained bonded until the age of 18 (Bush) came into effect. Subsequent to this, laws that abolished slavery permitted the acquisition of free labour through apprenticeships. A British statue of 1833 , for instance, required that all former slaves served their exmasters for a period of six years under some form of apprenticeship (Bush). This was emulated in Cuba in 1880 when former slaves had to provide free services over the same length of time (Bush). The compulsory provision of free labour by former slaves to ex-masters was completely outlawed by the 1880 s wherever slavery was unconditionally and absolutely abolished.

While laws requiring free labour from former slaves no longer exist, the nature and form of contemporary slavery indicate that the absence of these laws did not eliminate forced servitude. New laws that have been established to protect children and adults alike from labour exploitation and slavery have also not been effective. Prominent among these is the Slavery Convention, which the United Nations (UN) General Assembly adopted in March 1927 to

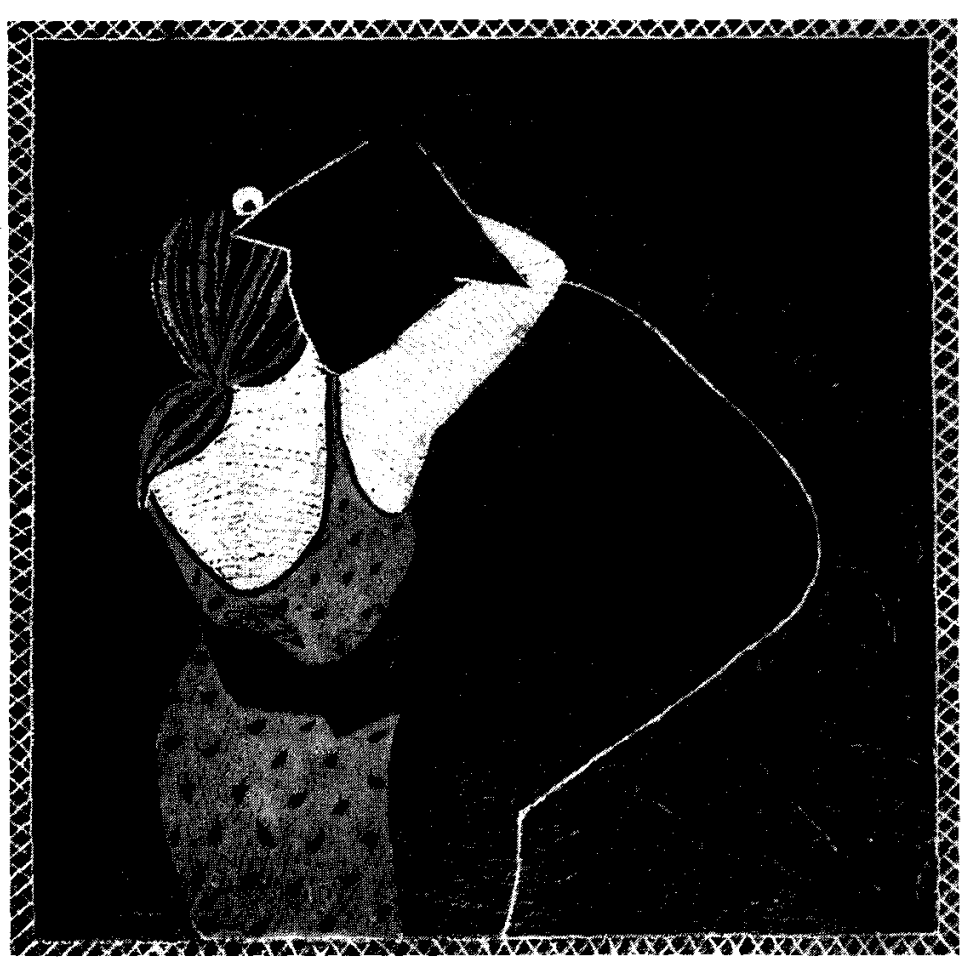

Rochelle Rubinstein, "Rescue Me," hand-dyed linocut print, 24 " 24 , " 1990.

prevent the development of forced labour into slave-like conditions.

Another important treaty is the 1956 Supplementary to the Slavery Convention. This was necessitated by events of the 1940s and '50s (ILO 2001a) when struggles by some European colonies for political independence coupled with labour exploitation that emerged from the Second World led to an increase in the illegal exploitation and trafficking of women and children (Derby). The 1956 Supplementary Convention had a specific focus on the protection of children. It prohibited bonded slavery, serfdom and

[a]ny institution or practice whereby a child or young person under the age of 18 years, is delivered by either or both of his natural parents or by his guardian to another person, whether for reward or not, with a view to the exploitation of the child or young person or of his labour.

More recent conventions such as Convention 138 concerning the minimum age for admission to employment (1973); the Convention on the Rights of the Child (1989), and Convention No. 182 against Worst Forms of Child Labour Convention (1999) were also established to 
specifically protect children across the globe. These provisions, however, are not adequate. More and more children continue to be kidnapped, trafficked, and forced into sexual or domestic slavery. Today, it is estimated that over 400 million children work around the world (Cox). An estimated 250 million of these child workers are exploited, some under slavery-like conditions.

The failure to prevent the trafficking of children may be attributed to a lack of commitment on the part of countries that have ratified international laws and treaties, and their participation in the global economy that usually conflicts with their local needs. Although women play indispensable roles in the continued survival of their

\section{Today, it is estimated that over 400 million children work around the world. An estimated 250 million of these child workers are exploited, some under slavery-like conditions.}

families, development programs in low-income countries, especially those recommended and developed under the direction of the World Bank and the International Monetary Fund (IMF), often overlook women's and children's positions in their families (see Gladwin). These programs, which often fail to meet the needs of the people, can exacerbate women's and children's poor living conditions, thus making them more vulnerable to economic exploitation and enslavement

\section{Postcolonial Contexts}

Population explosions in the period immediately following World War II together with the rapid socioeconomic changes occurring at the same time have significantly contributed to the rise in forms of contemporary slavery (Bales 2000, 1999). The largest proportion of population increases following WWII occurred in the Third World while the growth of the world economy severely impacted the small scale farming communities in the those regions (Bales 2000, 1999). This led to excess labour supply causing wages to plummet significantly. The effect of this, according to Bales $(2000,1999)$, was the willingness of workers to offer their services even under slavery-like conditions. The postcolonial era in some African and Asian countries, Bales (2000) argues, was further afflicted by wars and military dictatorships that resulted in the siphoning of the already limited resources ourside their economies to obtain arms and weaponry. These conditions worsened when the International Monetary Fund (IMF) and the World Bank initiated development programs, such as Structural Adjustment Programs (SAPs), which failed to stimulate growth and stability in participating poor countries (Donkor; Gladwin). Most affected by all this are women and children, the most vulnerable members of Third World families.

\section{Economic Issues}

Efforts on women's parts to pursue greener pastures in the developed Europe and North America have often been thwarted and exploited by traffickers. The economic gap between poor and rich countries, migration decision processes, and the availability or lack thereof of social capital at their destinations, make it easy for traffickers to exploit women and children. According to the new economics of migration theorists, migration decisions are collectively taken within the household, the family or the community so as to maximize expected income while minimizing risks (Stark; Taylor cited in Massey).

Martin Verlet (2000) suggests, for instance, that "domestic deregulation," i.e. "the break-up of family units" impacted by liberalization policies of SAPs necessitated the abuse of children's labour in Ghana. As Verlet points out, children enter the labour force through family channels, allowing the "employers" to adopt a pseudo-parental role, which serves to obscure the extent of exploitation being meted out to the child victims. Besides financial interests, however, parents entrust their children to other families because of their desire to seek better lives for them (ILO 2001a). The families' financial interests in their members' migration is characteristic of many households in low-income countries. According to ILO and United Nations Children's Fund reports, successful migrants usually have to share their gains with their entire families. In extreme cases, the victims may not even see their incomes at all. As much as 45 per cent of domestic workers who participated in a United Nations Children's Fund research project in Bangladesh claimed they never saw their wages, while 25 per cent of them were never paid at all. The bonding of children's labour in settlement of family debts (Bales; Burra; Mishra; United Nations Children's Fund) also attests to the benefits that accrue to families when their members are enslaved.

Migrant workers, however, are reliant not only as material resources, but on what Massey refers to as "social capital," which he defines as "... the sum of the resources, actual or virtual, that accrue to an individual or a group by virtue of possessing a durable network of more or less institutionalized relationships of mutual acquaintance and recognition" (43). Access to a good social network enables migrants to identify potential host countries, information about job opportunities, and legal immigration processes among others. Unfortunately these social networks also expose vulnerable women and children to sex tourists and traffickers.

Advances in information technology and the "global media" (Grosfoguel and Cervantes-Rodriquez) are potential sources of social networks for prospective migrants. 
International television and radio networks, the internet, and the print media impact contemporary slavery through the role they play in the global media, a major component of the capitalist world system being experienced today. According to Ramón Grosfoguel and Ana Margarita Cervantes-Rodríguez, the global media is responsible for the positive projection of the cultures of core (industrialized) countries with respect to race, gender and heterosexuality. The "advancedness" of core or industrialized countries is "pojected in these media propaganda while other cultures are denigrated, thus creating a desire among the people in the periphery to migrate to the core" (Derby 26). This has two effects-people from the periphery are driven to yearn for the "good things" in the core, while sex tourists and traffickers are invariably provided information about the vulnerable category of women and children in the periphery. For example, there are various internet sites advertising children for sexual exploitation. A handbook of international prostitution, the World Sex Guide, was available for free on the internet and advertised that children as young as six are available in Phnom Penh--the capital of Cambodia_-for US\$3.00 (Chidey).

Traffickers promise their victims jobs. Victims hoping for jobs in other countries may sign contracts similar to indentures and collect loans from their exploiters in order to migrate. The International Organization for Migration (IOM) (2000a) reports that about 400 Nigerian women were trafficked into the Netherlands between 1996 and 2000 for prostitution. Ethiopian women trafficked to Lebanon work as domestic servants and are often subjected to rape, physical abuse, nonpayment of salaries, and debt bondage (IOM 2000c). It is also estimated that 200 Nepalese women and children are trafficked into India every month to work in brothels (IOM 2000b). In all these cases, local and foreign recruiters work together to lure the victims into believing that decent jobs really exist and are waiting for them at the intended destinations.

\section{Trafficking Girl Children}

This paper identifies different types of contemporary slavery that have a profound impact an girl children. The first is observed in domestic servitude. It is estimated that 90 per cent of domestic workers around the world are girls (United Nations Children's Fund; UNCHR). The dominance of girls in domestic slavery is both traditional and strategic. Girls are easier to withdraw from school, and to serve as an additional source of income. Limiting them to household chores is also considered a means to protect women and girls in some cultures (Verlet; United Nations Children's Fund). Child domestic slaves around the world work 10 to 18 hours a day, usually throughout the weck and often without pay (United Nations Children's Fund; $\mathrm{UNCHR}$ ). Some of them may receive meager salaries as is the case in Rwanda where children aged between 10 and 14 years received US $\$ 4.00$ a month for working 16 hours a day, seven days a week throughout the year (United Nations Children's Fund). Some never see any of the pay that is promised to them. In addition, most of them suffer sexual abuse while they are still young (UNCHR; Bee). It is estimated that 60 per cent of Peruvian men who grew up with domestic servants had their first sexual encounter with the victims of domestic slavery (UNCHR; United Nations Children's Fund), while 80 per cent of the domestic workers in Fiji are also exploited sexually (UNCHR).

Newspaper reports abound in the treatment meted out to these domestic servants. David France reports on two African teenage girls who were enslaved as domestic servants in the 1990 s. The two worked approximately 16

\section{Bonded children, some of whom are below the ages of ten, work under hazardous conditions in India's bead, carpet, glass, and cigarette-making factories to repay their families' loans.}

hours a day, seven days a week for years. They were sexually abused, threatened with deportation if they stepped outside, and were never enrolled in school as had been promised. They were never paid for their services. A recent report involves the indictment of Ghana's Deputy Minister for Economic Planning for a role she played in her daughter's enslavement of a Ghanaian teenager in the United States (Ghanaweb). In Ivory Coast in 2001 also, a Ghanaian couple was arrested for enslaving seven Ghanaian girls aged between 15 and 18 (Ghanaweb). The couple assigned these girls to different households for domestic services and paid them only 16 per cent of their incomes.

Another category of contemporary slavery is found in agriculture and the manufacturing sectors. These industries employ significant numbers of children in Africa and Asia, according to International Labour Organization (2001a). In Cote d'Ivoire, children believed to have been trafficked from neighboring Mali and Burkina Faso work 10 to 15 hours a day without pay and under conditions that evoke chattel slavery. An estimated 10,000 to 15,000 children from Mali and Burkina Faso have been enslaved on plantations in Cote d'lvoire (ILO 2001a). Most of them are aged between nine and 16 years. Some of them were sold for only $\$ 25.00$, according to a cocoa farm owner who exploits child slaves (Sudarsan and Raghavan). The bulk of child slaves who work in the manufacturing sector are found in India (Burra; Mishra). Bonded children, some of whom are below the ages of ten, work under hazardous conditions in India's bead, carpet, glass, and cigarette-making factories to repay their families' loans and the accruing interests (Mishra 2000). 
It is difficult for some people to come to terms with the fact that slavery continues to exist in the current conjuncture. It is, however, important to recognize that the majority of contemporary slaves are children who cannot make independent decisions. I believe prostitutes constitute another category of contemporary slaves. Many trafficking victims, including children, are forced into prostitution. Child prostitutes in Tanzania, for, instance are between 10 and 17 years old (ILO 2001b). Other International Labour Organization (ILO) reports show that there are approximately 200,000 child prostitutes in Thailand, 60,000 in the Philippines, 250,000 in Brazil and over 200,000 in the United States. While there have been arguments as to whether prostitution should be categorized as slavery (see, for example, Kempadoo and Doezema), I agree with Kathleen Barry's perception of prostitution as a form of sexual exploitation that has the same magnitude as rape, female genital mutilation, incest and battering.

\section{Conclusion}

To conclude, this paper recommends that scholars and activists campaigning against all forms of labour exploitation, as well as those working to support and/or rehabilitate victims, consider the backgrounds of the victims, the processes of their recruitment, their working conditions, their ages, and the kind of orientation they received when they were recruited. Efforts to support and protect the human rights of trafficked persons must address the stigma attached to prostitution, domestic servitude, and slavery in general in almost all societies.

Contemporary slavery is different from past forms of chattel slavery only to the extent that contemporary slaves are not permanently "owned." Nevertheless, as long as the new slave's labour remains the "property" of their perpetrators, contemporary slaves experience as much alienation and dehumanization as traditional slaves of the past.

I believe contemporary slavery has the most profoundly negative impact on the lives of women and girls. Women and girls feel its effects far more than their male counterparts in the agricultural, manufacturing, domestic work and sex trade industries., and are impacted in both the private and public spheres. This is why I have argued that contemporary slavery could thus be defined most specifically as the slavery of women and girls.

C. Nana Derby is a Ph.D. student in comparative sociology at the Florida International University. Her academic interest in contemporary slaves started with her interactions with and sympathy for Ghana's maidservants.

\section{References}

Archer, L. J. Ed. Slavery and Other Forms of Unfree Labour. New York: Routledge, 1988.
Bales, K. New Slavery: a Reference Book. California: ABCCLIO, 2000.

Bales, K. Disposable People. California: University of California Press, 1999.

Barry, K. Female Sexual Slavery. New York: New York University Press, 1984.

Bee, E. (1998). The Other Side of the Kitchen Door: Domestic Service in Lima, Peru. Unpublished M.A. thesis, Department of Sociology and Anthropology, Florida International University, Miami, 1998.

Burra, N. Born to Work: Child Labour in India. Delhi: Oxford University Press, 1995.

Bush, M. L. Servitude in Modern Times. Massachusetts: Polity Press, 2000.

Chidey, J. "A Fight to Save the Children: Activists Battle the Sexual Exploitation of the Kids." Maclean's 109 (36) (1996): 20-22.

Cox, K. E. "The Inevitability of Nimble Fingers? Law, Development, and Child Labour." Vanderbilt Journal of Transnational Law 32 (1) (1999): 115(1).

Derby, C. N. A Conceptual Framework for Understanding Contemporary Child. Unpublished M.A. thesis, Department of Sociology and Anthropology, Florida International University, Miami, 2003.

Donkor, K. Structural Adjustment and Mass Poverty in Ghana. Aldershot: Ashgate Publishing Ltd., 1997

Engerman, S., S. Drescher and R. Paquette. Eds. Slavery. Oxford: Oxford University Press, 2001.

France, D. "Slavery's New Face." Newsweek 118 (6255) (2000): 84-89.

Ghanaweb. "Ghanaian Couple Arrested for Child Slavery." 2002. http://ghanaweb.com/GhanaHomePage/ NewsArchive/artikel.php?ID=20696

Ghanaweb. "Child Traffickers Arrested." 2001. http:// www.ghanaweb.com/GhanaHomePage/NewsArchive/ artikel.php? ID $=14633$

Gladwin, C. Ed. StructuralAdjustment and African Women. Florida: University of Florida Press, 1991.

Grosfoguel R. and A. M. Cervantes-Rodriquez. The Modern/Colonial/Capitalist World-System in the Twentieth Century: Global Processes, Antisystemic Movements, and the Geopolitics of Knowledge. Connecticut: Preager Publishers, 2002.

International Labour Organization (ILO). Stopping Forced Labour: Global Report Under the Follow-up to the ILO Declaration on Fundamental Principles and Rights at Work. 2001a. http://ilo.org/public/english/standards/ $\mathrm{decl} / \mathrm{publ} / \mathrm{reports} / \mathrm{report} 2$, htm.

International Labour Organization (ILO). Tanzania Children in Prostitution: A Rapid Assessment. $200 \mathrm{lb}$. http://ilo.org/public/english/standards/ipec/simpoc/ tanzanial.

International Organization for Migration (IOM). "Trafficking in Nigerian Women to Work as Prostitutes in Europe." Trafficking in Migrants: Quarterly Bulletin $20(2000 a): 4$. 
International Organization for Migration (IOM). "Southern Asian Convention for Combating trafficking in Women and Children." Trafficking in Migrants: Quarterly Bulletin 20 (2000b): 3.

International Organization for Migration(IOM). "Ethiopian women Trafficked to the Arab Countries." Trafficking in Migrants: Quarterly Bulletin 20 (2000c): 3.

Kempadoo, K. and J. Doezema. Global Sex Workers: Rights, Resistance, and Redefinition. New York: Routledge, 1998.

Massey, D. S. "Why Does Immigration Occur? A Theoretical Synthesis." The Handbook of International Migration. Eds. C. Hirschman, P. Kasinitz and J. DeWind. New York: Russell Sage Foundation, 1999.

Meltzer, M. All Times, All Peoples: A World History of Slavery. New York: Harper and Row, Publishers, 1980.

Mishra, L. Child Labour in India. New York: Oxford

\section{PATIENCE WHEATLEY}

\section{Evasions}

Your friend

the psychologist reproves you

for not wanting to live beside the prison -

you explain that at Versailles

you felt a terrible sadness

as if the misery of Marie Antoinette

(whose portrait

painted when she was only thirty-eight

was of an old woman)

had sunk into the rectangular

stones, the glossy floors, even

the flower beds in geometric patterns

of scarlet, purple, white

not less because it was a queen's despair-

and if Marie Antoinette didn't understand why she was hated

nor does the imprisoned terrorist

who tell us his crimes are our fault.

Your friend

the psychologist

doesn't mind your avoiding Versailles:

it's far away in France

and only history.

Patience Wheatley has had two collections of poetry published by Goose Lane Editions and lives in Kingston, Ontario.
University Press, 2000.

Stark, O. The Migration of Labour. Massachusetts: B. Blackwell, 1991.

Sudarsan, R. and C. Raghavan. "Sweet, Beloved Chocolate: A Product of Child Slavery." The Miami Herald 283 (1) (2001): 24A.

United Nations Children's Fund. The Innocenti Digest. Florence: International Child Development Center, 1999. United Nations Commission on Human Rights (UNCHR). The Relationship Between Child Domestic Servitude and the Sexual Exploitation of Children. 2002. <http://www.antislavery.org/archive/submission/ submission2002-childlabour.htm>

Verlett, M. "Growing Up In Ghana: Deregulation and the Employment of Children." The Exploited Child. Ed. Schlermer. New York: Zed Books, 2000.

\section{KAREN DELL KINNISON}

\section{Driftwood}

I let you go a little bit today like loosening a twine rope. My wood barrel heart floated out, not far, wobbling on the waves.

When it reached the boundary of its passion, (which is infinite), it pulled taut, back into this definite love that is like an ending.

This love is gravity force or magnetic want. My mineral heart cannot help but yearn to return to original ore.

The attraction imprisons me; I cannot break orbit but circle loops around love. I am dizzy, wracked by false freedom. Even now I skirt the composition of your soul, its familiar form and range. Our rust iron hearts are anchored Like sunken ships beneath the sea, too heavy with feeling to drift.

Wise, you know the lure of this bond, It is you who loosens the rope.

You know that fate has tied our hearts and that I always will return to you.

Karen Dell Kinnison's poetry has been published in The Texas Review, South Dakota Quarterly, Bottomfish, The Amethyst Review, Poettalk, and the Yearbook of American Poetry. She lives in Charlotte, North Carolina. 